\title{
Triptych about Death
}

\author{
Tríptico acerca de la muerte
}

Lucía Villanea Morales

Sección de Lenguas Modernas

Sede de Guanacaste, Universidad de Costa Rica

Costa Rica

\section{The Noiseless Guest}

$\mathrm{T}$ his gloomy rain has cried all day, and as I rush to shut the window, an alien moth is perched along. Its feathery antennae it stretches, and its long tongue it unrolls, sucking all my secret thoughts.

This is insane,

I hear it calling my name....

Crying that rain has now stopped, and gone unseen is the moth, Filled I am by this unknown calm, my body weighs no burden anymore,

- There's a lady lyin' on the floor!

- Why's she wearin' my gown?

\section{A Fly in my Soup}

here's a Fly in my soup, and He fixedly stares at me. The Waiter ignores my call, and the Fly stirs my guts. Thousands of lenses gaze, and there's no way to escape.

His wings begin to sway, and madly He pounces against.

Panting!

Quivering!

Sweating!

Self-control surrenders! Strength weakens!

Willpower unnerves!

The Fly hinders my sight, and everything turns dark. Roughly my breathing thwarts, and away my spirit dies. A deadly disease is the Fly and there's nothing but cry. My all me... bones and soul, the Fly has managed to dry. 


\section{Praying Death}

$\mathrm{U}$ nderneath my feet the dry leaves break as I walk by. In a close distance an iron gate rattles as the wind cries.

Beyond darkness a deadly presence muddles my sight,

By turning around its head to reach my fear It tries.

Holding a prayer's mien, It freezes my raving mind

Nearing enough to reveal its striking legs by my side.

Like the Mantid together I keep my hands,

And about to fall down on my knees I am Begging not to be its unescapable sacrifice;

And straight in its eyes the Beast I descry Reclaiming its power as It smells my fright,
And with crystals of fear, woe my will stabs.

Domain is claimed as It slightly sways

Craving to pounce its prey against. Shadow falls in the depths of my pain; My hour has come; my spirit slips away. This natural journey nothing can break; And farther the grave, I will be erased.

Beyond the veil no grief awaits me, they say...

Ahead a sound of water rushes filling the space.

In this point of no return to silent my heart fades;

On a void I float as my life over I contemplate.

While facing the futility of stepping back in time,

Into the Mantid's rotten aliment my body dies. 